\title{
A novel mutation causing mild, atypical fumarylacetoacetase deficiency (Tyrosinemia type I): a case report David Cassiman*1, Renate Zeevaert ${ }^{1}$, Elisabeth Holme ${ }^{2}$, Eli-Anne Kvittingen ${ }^{3}$ and Jaak Jaeken ${ }^{1}$
}

Address: ${ }^{1}$ Center for Metabolic Diseases, Leuven University Hospitals, Leuven, Belgium, ${ }^{2}$ Department of Clinical Chemistry, Salhgrenska Hospital, Göteborg, Sweden and ${ }^{3}$ Institute of Clinical Biochemistry, University of Oslo, 0027 Oslo, Norway

Email: David Cassiman* - david.cassiman@med.kuleuven.be; Renate Zeevaert - renate.zeevaert@uzleuven.be; Elisabeth Holme - elisabeth.holme@clinchem.gu.se; Eli-Anne Kvittingen - david.cassiman@med.kuleuven.be; Jaak Jaeken - jaak.jaeken@uzleuven.be

* Corresponding author

Published: 15 December 2009

Orphanet Journal of Rare Diseases 2009, 4:28 doi:10.1186/1750-1172-4-28

This article is available from: http://www.ojrd.com/content/4/I/28

(C) 2009 Cassiman et al; licensee BioMed Central Ltd.

This is an Open Access article distributed under the terms of the Creative Commons Attribution License (http://creativecommons.org/licenses/by/2.0), which permits unrestricted use, distribution, and reproduction in any medium, provided the original work is properly cited.

\begin{abstract}
A male patient, born to unrelated Belgian parents, presented at 4 months with epistaxis, haematemesis and haematochezia. On physical examination he presented petechiae and haematomas, and a slightly enlarged liver. Serum transaminases were elevated to 5-10 times upper limit of normal, alkaline phosphatases were $1685 \mathrm{U} / \mathrm{L}(<720)$, total bilirubin was $2.53 \mathrm{mg} / \mathrm{dl}(<1.0)$, ammonaemia $69 \mu \mathrm{M}(<32)$, prothrombin time less than $10 \%$, thromboplastin time $>180 \mathrm{~s}(<60)$ and alpha-fetoprotein $29723 \mu \mathrm{g} / \mathrm{L}(<186)$. Plasma tyrosine $(65 \mathrm{I} \mu \mathrm{M})$ and methionine $(1032 \mu \mathrm{M})$ were strongly increased. In urine, tyrosine metabolites and 4-oxo-6-hydroxyheptanoic acid were increased, but succinylacetone and succinylacetoacetate - pathognomonic for tyrosinemia type I were repeatedly undetectable. Delta-aminolevulinic acid was normal, which is consistent with the absence of succinylacetone. Abdominal ultrasound and brain CT were normal.

Fumarylacetoacetase (FAH) protein and activity in cultured fibroblasts and liver tissue were decreased but not absent. 4-hydroxyphenylpyruvate dioxygenase activity in liver was normal, which is atypical for tyrosinemia type I. A novel mutation was found in the FAH gene: c.103G>A (Ala35Thr). In vitro expression studies showed this mutation results in a strongly decreased FAH protein expression.

Dietary treatment with phenylalanine and tyrosine restriction was initiated at 4 months, leading to complete clinical and biochemical normalisation. The patient, currently aged 12 years, shows a normal physical and psychomotor development.

This is the first report of mild tyrosinemia type I disease caused by an Ala35Thr mutation in the $\mathrm{FAH}$ gene, presenting atypically without increase of the diagnostically important toxic metabolites succinylacetone and succinylacetoacetate.
\end{abstract}




\section{Introduction}

Type I tyrosinemia (OMIM +276700), also called hepatorenal tryosinosis, is a severe inborn metabolic disease affecting the tyrosine degradation pathway. It often presents with liver disease or liver failure with predominant bleeding tendency, Fanconi syndrome and/or rickets (for a comprehensive review, see [1]). Type I tyrosinemia is caused by a mutation in the gene encoding for the fumarylacetoacetate hydrolase or fumarylacetoacetase (FAH) enzyme, an enzyme in the tyrosine degradation pathway. Deficiency of this enzyme causes intracellular accumulation of fumarylacetoacetate (FAA), a tyrosinederived metabolite upstream of the deficient FAH enzyme. FAA is thought to be genotoxic and therefore carcinogenic. Intracellular FAA is rapidly degraded to succinylacetone (SA) and succinylacetoacetate (SAA), which are also thought to be carcinogenic. Patients with type I tyrosinemia can also develop acute neuropathic pains or polyneuropathy with respiratory failure, reminiscent of acute porphyria, due to inhibition of heme-synthesis at the level of aminolevulinic acid dehydratase, by the produced toxic metabolites of tyrosine degradation [1].

The diagnosis of type I tyrosinemia is based on the presence of liver disease, kidney disease and/or rickets, increased tyrosine and methionine in plasma and the presence of SA in urine and blood and SAA in urine. In addition to SA and SAA, the presence of 4-oxo-6-hydroxyheptanoic acid in urine has also been described as pathognomonic [2]. The presence of SA and SAA is considered pathognomonic for the disease. Up till now, no type I tyrosinemias without SA or SAA in urine have been described [1]. The diagnosis of type I tyrosinemia is confirmed by measurement of FAH enzyme activity in cultured fibroblasts (or on liver tissue) and/or detection of disease-causing mutations in the FAH gene. In total, 44 FAH mutations are listed in the Human Genome Mutation database http://www.hgmd.cf.ac.uk.

Type I tyrosinemia is treated with a protein-restricted diet, amino acid supplements low in tyrosine, phenylalanine and methionine, and nitisinone. Nitisinone is a drug that inhibits 4-hydroxyphenylpyruvate dioxygenase, an enzyme upstream of FAH, thereby preventing the formation of the toxic compounds FAA, SA and SAA [1]. Typically, the activity of this enzyme is already reduced in type I tyrosinemia, presumably be feedback-inhibition of the accumulating toxic end-products in the diseased patient.

The natural history of the typical disease is an evolution to liver failure, cirrhosis with hepatocellular carcinoma, endstage renal failure, acute neuropathic pains and hypertrophic cardiomyopathy.
The evolution of the disease has improved considerably since the introduction of nitisinone treatment, but depending on the age at diagnosis and start of treatment development of liver and kidney disease is not entirely excluded. Especially the occurrence of hepatocellular carcinoma is a dreaded complication.

\section{Materials and methods Isolation of RNA and Northern blotting}

The isolation of total RNA from fibroblasts, electrophoresis, blotting and hybridisation with a 32P-labelled single stranded FAH probe, was performed as described previously [3]. The membranes were reprobed with pig $\beta$-actin cDNA as control.

\section{Western blotting}

Was performed according to Berger et al. [4].

\section{Genomic PCR, sequencing and restriction analysis}

A genomic DNA product of 252 bp across FAH exon 2 was PCR amplified with primers 5'-GGACTCTTCAATAGACAGG-3' (sense, intron 1) and 5'-CCACAGTAAGTGCCACTGAG-3' (antisense, intron 2) and used for direct sequencing (Thermo Sequenase radiolabeled terminator cycle sequencing kit from Amersham, The Netherlands).

For enzyme restriction analysis a 175 bp PCR product across the mutation was amplified by 30 cycles of $94^{\circ} \mathrm{C}$ for $30 \mathrm{sec}$ and $60^{\circ} \mathrm{C}$ for $60 \mathrm{sec}$, followed by $3 \mathrm{~min}$ final extension at $72^{\circ} \mathrm{C}$. The primers were $5^{\prime}$-ATCTTCCTCCTAGCCAAGACCGAGGATAGGGGTG-3' (sense) and 5'CCACAGTAAGTGCCACTGAG-3' (antisense). A mismatch (underlined) in the sense primer together with the Ala35Thr mutation creates a restriction site for Bst EII. The PCR assay contained, in a total volume of $100 \mu \mathrm{l}, 5-10 \mu \mathrm{l}$ of cell lysate, $10 \mu \mathrm{l}$ of PCR buffer, $0.2 \mathrm{mM}$ of each dNTP, $40 \mathrm{pmol}$ of each primer, $2 \mu \mathrm{mol} \mathrm{MgCl} 2$ and $1 \mu \mathrm{l}$ Dynazyme DNA polymerase. The PCR products were digested with either HaeIII or Bst EII and electrophoresed on 3.5\% NuSieve minigels. With HaeIII the 175 bp PCR product without mutation is digested into fragments of 142 and $33 \mathrm{bp}$. With Bst EII the product with the Ala35Thr mutation is digested into fragments of 141 and $34 \mathrm{bp}$.

\section{Mutagenesis and expression analysis}

Mutagenesis using the Altered Sites In Vitro Mutagenesis System (Promega), expression analysis using TnT Coupled Reticulocyte Lysate System (Promega), determination of FAH activity of the translated products, and autoradiography of 35 S-methionine-labeled translation products subjected to PAGE were performed as previously described [3]. 
Liver enzyme activities and urinary and blood organic acid analysis

Were performed as described previously $[2,5]$.

\section{Case Description}

A 4 month old boy, born at 37 weeks of gestation, to nonconsanguineous Caucasian parents presented at the emergency department with epistaxis, hematemesis and hematochezia. He was born following a pregnancy complicated with maternal oedema and preterm contractions. On physical exam at 4 months, petechiae, a subconjunctival bleeding in the left eye and a friable haemangioma on the inside of the left cheek were noted. The liver was slightly enlarged. Serum transaminases were elevated to 5-10 times upper limit of normal, alkaline phosphatase was $1685 \mathrm{U} / \mathrm{L}(<720)$, total bilirubin was $2.53 \mathrm{mg} / \mathrm{dl}(<1.0)$, ammonaemia was $69 \mu \mathrm{M}(<32)$, prothrombin time was less than $10 \%(>70)$, thromboplastin time was $>180 \mathrm{~s}$ $(<60)$ and alpha-fetoprotein was $29723 \mu \mathrm{g} / \mathrm{L}(<186)$.

Hepatitis caused by drugs, hepatitis viruses or hepatotropic viruses was excluded.

Plasma tyrosine $(651 \mu \mathrm{M})$ and methionine $(1032 \mu \mathrm{M})$ were strongly increased. In urine, tyrosine metabolites and 4-oxo-6-hydroxyheptanoic acid were increased, but SA and SAA were repeatedly undetectable. Delta-aminolevulinic acid was normal, which is consistent with the absence of SA. There was no tubulopathy, skeletal X-ray showed no rickets. Abdominal ultrasound and brain CT were normal.

Treatment with restriction of natural protein and amino acid formula low in phenylalanine and tyrosine was initiated at 4 months. Nitisinone was initially not started because of absence of the supposedly toxic metabolites of tyrosinemia type I and complete clinical and biochemical normalisation on diet (normal liver tests, alpha-fetoprotein, coagulation tests).

Fumarylacetoacetase (FAH) mRNA in fibroblasts was normal (Fig. 1). FAH protein and activity in cultured fibroblasts (Fig. 1) and liver tissue (Table 1) were decreased but not absent. 4-hydroxyphenylpyruvate dioxygenase activity in liver was normal, which is atypical for tyrosinemia type I. A novel mutation was found in the FAH gene: c.103G >A (Ala35Thr). (Fig. 2) Homozygosity for this mutation in the patient, heterozygosity in both his parents, was shown by restriction analysis with HAEIII and BstEII. (Fig. 3) In vitro expression studies showed this mutation resulted in absence of FAH protein expression. (Fig. 4)

Because of clinical and biochemical normalisation (table 2 and 3 ), the diet was terminated at the age of 22 months.

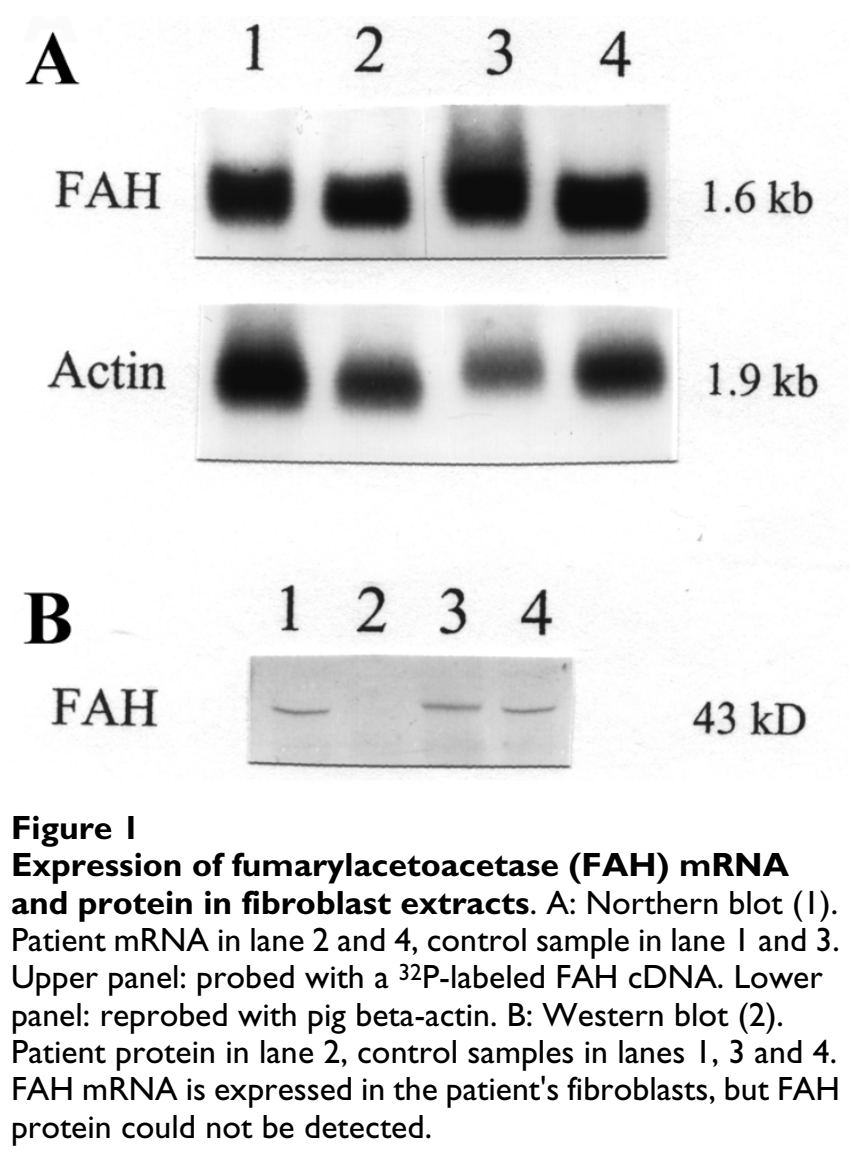

Parameters remained normal during follow-up. At the age of 6 years the diet was reintroduced together with nitisinone treatment $(0.5 \mathrm{mg} / \mathrm{kg}$, later increased to $1.0 \mathrm{mg} / \mathrm{kg})$ after the identification of a hypointense lesion on MRI of the liver. The lesion was considered suspicious and was resected. Pathological examination showed a region of disturbed microcirculation, no arguments for malignancy. Electron microscopy of the tissue surrounding the resected lesion showed enlarged mitochondria with paracrystalline inclusions together with hypertrophy of the Golgi apparatus. These findings are non-specific, but suggestive of toxicity. Annual follow-up liver MRI up till now (12 years of age) has shown no focal lesions. The patient's psychomotor development is normal. His renal function is normal. He is still on diet and nitisinone therapy.

\section{Discussion}

We report here a case of a mild Type I Tyrosinemia, presenting typically with liver disease (jaundice, bleeding tendency), increased tyrosine and methionine in plasma, but absence of the pathognomonic markers SA and SAA from urine. The diagnosis of type I tyrosinemia is supported by the demonstration of 4-oxo-6-hydroxyheptanoic acid in urine, a strongly decreased but measurable 


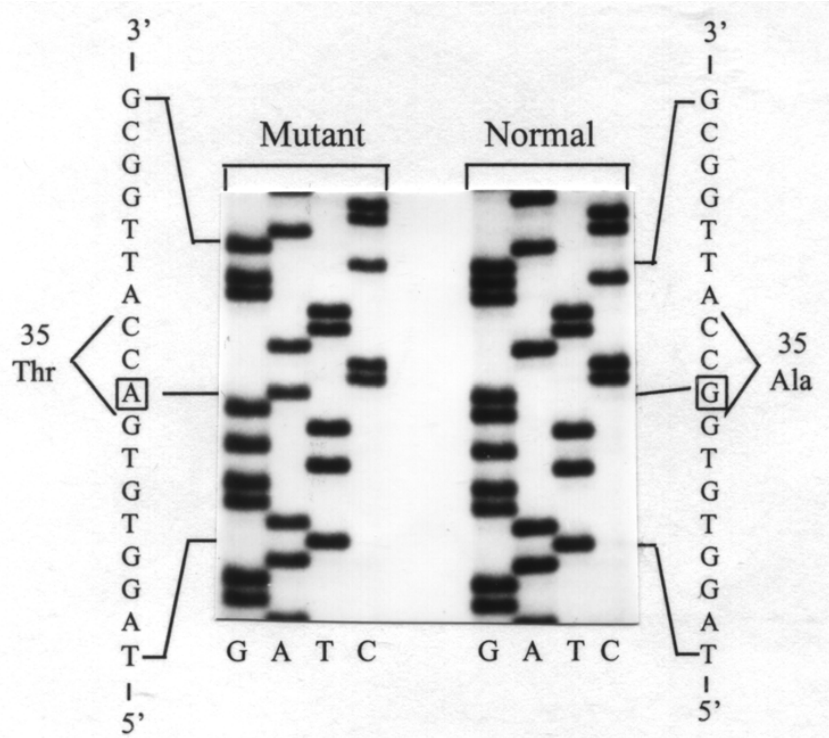

Figure 2

Identification of the Ala35Thr mutation. PCR-amplified genomic DNA was sequenced and revealed a $G$ to $A$ transition in the first nucleotide of codon 35 in exon 2 of the $F A H$ gene, leading to a substitution of Ala by Thr.

FAH enzyme activity in liver tissue and fibroblasts and the demonstration of a novel mutation in the FAH gene (Ala35Thr). In the first 6 years following diagnosis, the condition was successfully managed with a tyrosine/ methionine-restricted diet, resulting in rapid and complete resolution of liver disease.

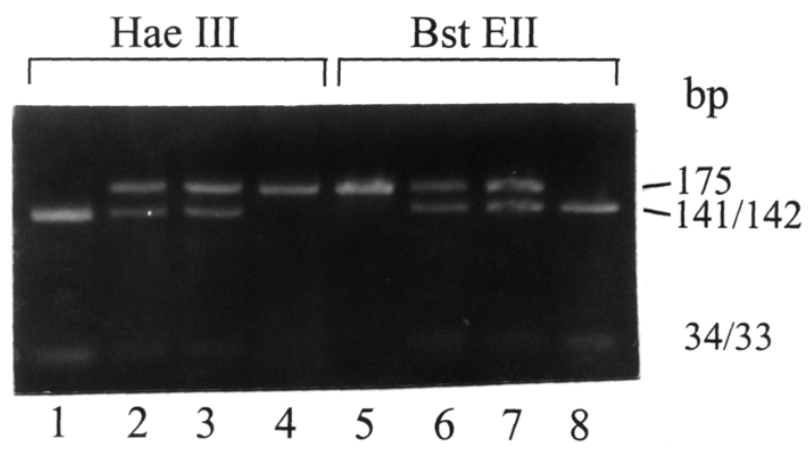

Figure 3

The Ala35Thr mutation can be confirmed by restriction analysis. Lanes I and 5: control. Lanes 2 and 6: the patient's mother. Lanes 3 and 7: the patient's father. Lanes 4 and 8: the patient. Restriction analysis with HAEIII and BstEII, on DNA extracted from blood, confirms heterozygosity for the Ala35Thr mutation in both parents and homozygosity in the patient.

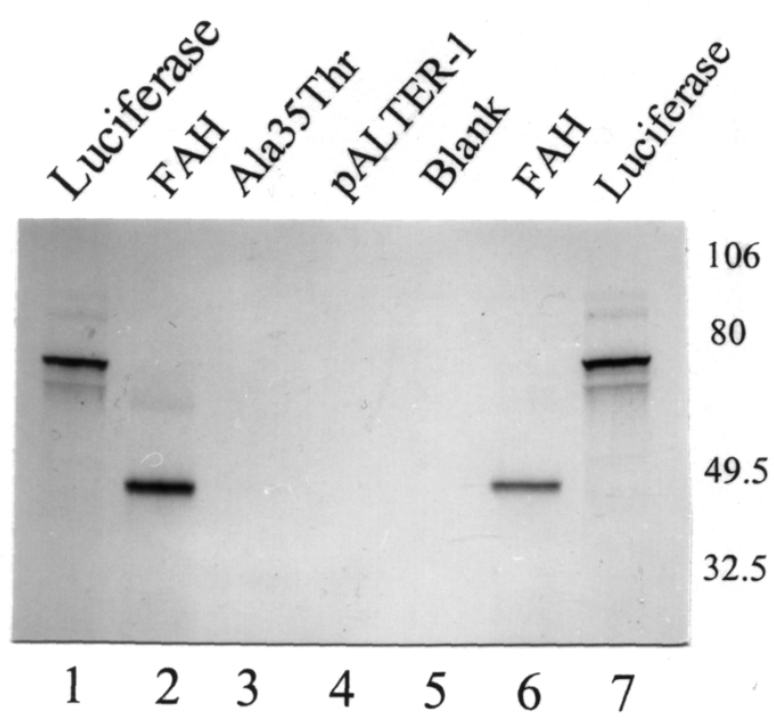

Figure 4

Expression analysis of Ala35Thr mutated FAH. Using the TnT Coupled Reticulocyte Lysate System (Promega) (2), wild-type $\mathrm{FAH}$ and mutated $\mathrm{FAH}$ were expressed. An autoradiography of ${ }^{35} \mathrm{~S}$-methionine-labeled translation products separated by polyacrylamide gel electrophoresis is shown. Lanes I and 7: luciferase expression (control). Lanes 2 and 6: expression of $43 \mathrm{kDa} F A H$ control. Lane 3: expression of FAH mutant with Ala35Thr. Lane 4: plasmid without insert. Lane 5: no DNA control. Ala35Thr mutation of the FAH gene leads to absence of protein expression.

Table I: Liver enzyme activities

\begin{tabular}{lllll}
\hline & Biopsy I & Biopsy II & Tyr type III & Controls \\
\hline FAH & 2.2 & 1.8 & 33 & $4 I(38.8-46.4)$ \\
$4-H P D$ & $1 \mathrm{I}$ & 8.7 & 0.2 & $15(10.8-18.4)$ \\
ASAT & 3472 & 2669 & 2490 & $173 \mathrm{I}, 164 \mathrm{I}$ \\
ALAT & 700 & 810 & 1340 & 665,1034 \\
LDH & 3315 & 2223 & 3420 & 3755,3045 \\
\hline
\end{tabular}

Column I shows the result of a first biopsy in the presented patient (at diagnosis), the second column of a confirmatory biopsy in the same patient. Column 3 shows the results in a type III tyrosinemia, for comparison. The last column shows control values. $\mathrm{FAH}$ is clearly decreased, but measurable in both biopsies in our patient (approx. 5\% of normal). 4-HPD is unexpectedly not equally decreased as would be expected in type I tyrosinemia, also contrasting with the value measured in the type III tyrosinemia biopsy. The fact that 4-HPD is not decreased, is compatible with the absence of SA and SAA in our patient. ASAT, ALAT and LDH are internal controls, demonstrating the quality of the tissue samples used.

$\mathrm{FAH}$ : fumarylacetoacetate hydrolase; 4-HPD: 4-

hydroxyphenylpyruvate dioxygenase; ASAT: aspartate transaminase; ALAT: alanine transaminase; LDH: lactate dehydrogenase 
Table 2: Urinary organic acid analysis results

\begin{tabular}{lllll}
\hline Age & $\mathbf{4}$ months & $\mathbf{5}$ months & $\mathbf{8}$ months & $\mathbf{1 8}$ months \\
\hline Succinylacetone & 0.2 & 0.1 & 0.1 & $\approx 0.1$ \\
Succinylacetoacetate & $\approx 0.1$ & $<0.1$ & $\approx 0.3$ & $<0.1$ \\
4-oxo-6-hydroxyheptanoic acid & 4 & 1 & 2 & 8 \\
creatinine, mmol/L & 3.1 & 1.6 & 3.1 & 3.2
\end{tabular}

A significantly increased excretion of aberrant tyrosine metabolites was detected, with 4-oxo-6-hydroxyheptanoic acid as the dominant metabolite. The excretion of phenolic tyrosine metabolites was not significantly increased: in the first sample 4-hydroxyphenylpyruvate was $7 \mathrm{mmol} / \mathrm{mol}$ creatinine, which can be considered as marginally increased (ref value in newborns $<10$, in infants $<5$ ). In later samples, we found $4-$

hydroxyphenylpyruvate $<1 \mathrm{mmol} / \mathrm{mol}$ creatinine (reference value $<5$ ) and 4-hydroxyphenyllactate $2 \mathrm{mmol} / \mathrm{mol}$ creatinine (reference value $<10$ ).

These values are in accordance with a normal 4-hydroxyphenylpyruvate dioxygenase activity (Table I).

Although apparently mild in presentation, we do not consider it likely that the disease only became clinically apparent, by the presence of an intercurrent problem, e.g. a viral or xenobiotic-induced hepatitis, since the most likely causes of hepatitis were excluded in this patient, by standard hepatitis work-up. The cause of the hepatitis episode in this patient, with a striking coagulopathy and highly increased $\alpha$-fetoprotein typical of Type I Tyrosinemia, was therefore most likely the suggested mild type I tyrosinemia.

In type I tyrosinemia patients with a cirrhotic liver, liver nodules demonstrating a reversion to the normal FAH genotype and showing normal FAH enzyme activity have been described [5]. The reversion is thought to result from a combination of mutation pressure exerted by the toxic compounds produced in these patients (FAA, SA, SAA), combined with a high rate of liver cell proliferation. In the patient reported here, there was no advanced liver disease or generalised nodular transformation at the time of biopsy, so the measured residual FAH enzyme activity is considered a genuine residual activity (of about $5 \%$ ). In the transgenic lethal albino mice, $0.3 \%-4.3 \%$ of normal expression of FAH was shown to be compatible with a normal life-span of the mice [6], which is concordant with the described evolution of our patient so far.

In our opinion, the normal SA and SAA in this patient is due to the residual activity of the FAH enzyme. The absence of the typical suppression of both the aminolevulinic acid dehydratase and 4-hydroxyphenylpyruvate dioxygenase, supports the observation that SA and SAA are low. Inversely, absence of suppression of these enzymes in the presence of type I tyrosinemia, supports

Table 3: Blood and urine biochemistry and enzymatic activities

\begin{tabular}{|c|c|c|c|c|c|c|c|c|c|}
\hline & $\begin{array}{l}\text { Age } \\
\text { Unit }\end{array}$ & Ref range & $\begin{array}{r}4 \\
\text { months }\end{array}$ & $\begin{array}{r}5 \\
\text { months }\end{array}$ & $\begin{array}{r}8 \\
\text { months }\end{array}$ & $\begin{array}{r}18 \\
\text { months }\end{array}$ & $\begin{array}{r}30 \\
\text { months }\end{array}$ & $\begin{array}{r}6 \text { years } \\
\text { Start NTBC }\end{array}$ & $\begin{array}{l}6 \text { years and } \\
1 \text { month }\end{array}$ \\
\hline \multicolumn{10}{|l|}{ BLOOD } \\
\hline $\begin{array}{l}\text { PBG synthase in } \\
\text { RBC }\end{array}$ & nkat/g Hb & $0.58-1.25$ & -- & 0.51 & 0.17 & 0.05 & 0.06 & 0.11 & 0.870 \\
\hline $\begin{array}{l}\text { Succinylacetone in } \\
\text { plasma }\end{array}$ & $\mu \mathrm{mol} / \mathrm{L}$ & $<0.1$ & 0.88 & 0.13 & $<0.1$ & 0.33 & 0.38 & 0.27 & $<0.10$ \\
\hline $\begin{array}{l}\alpha \text {-Fetoprotein in } \\
\text { serum }\end{array}$ & $\mu g / L$ & $<12$ & -- & 28000 & 50 & II & $<5$ & $<5$ & $<5$ \\
\hline Tyrosine in plasma & $\mu \mathrm{mol} / \mathrm{L}$ & $50-130$ & 693 & 36 & 73 & 96 & 112 & 130 & 381 \\
\hline $\begin{array}{l}\text { Phenylalanine in } \\
\text { plasma }\end{array}$ & $\mu \mathrm{mol} / \mathrm{L}$ & $40-120$ & 196 & 57 & 72 & 70 & 83 & 89 & 45 \\
\hline $\begin{array}{l}\text { Methionine in plasma } \\
\text { URINE }\end{array}$ & $\mu \mathrm{mol} / \mathrm{L}$ & $20-50$ & 1300 & 400 & 30 & 20 & 39 & 34 & 15 \\
\hline $\begin{array}{l}\text { 5-Aminolevulinic } \\
\text { acid }\end{array}$ & $\begin{array}{l}\mathrm{mmol} / \mathrm{mol} \\
\text { creatinine }\end{array}$ & $0-3$ & 6.9 & 5.3 & 8.8 & 25 & 17 & 7.9 & 3.5 \\
\hline Succinylacetone & $\begin{array}{l}\mathrm{mmol} / \mathrm{mol} \\
\text { creatinine }\end{array}$ & $<1$ & $<1$ & $<1$ & $<1$ & $<1$ & 1.1 & 0.3 & $<0.1$ \\
\hline Succinylacetoacetate & $\begin{array}{l}\mathrm{mmol} / \mathrm{mol} \\
\text { creatinine }\end{array}$ & $<1$ & $<1$ & $<1$ & $<1$ & $<1$ & $<1$ & $<0.3$ & $<0.1$ \\
\hline $\begin{array}{l}\text { 4-oxo-6- } \\
\text { hydroxyheptanoic } \\
\text { acid }\end{array}$ & $\begin{array}{l}\mathrm{mmol} / \mathrm{mol} \\
\text { creatinine }\end{array}$ & $<1$ & 4 & I & 2 & 8 & 4.2 & 6 & $<0.1$ \\
\hline NTBC in serum & $\mu \mathrm{mol} / \mathrm{L}$ & & -- & -- & -- & -- & -- & -- & 28.7 \\
\hline
\end{tabular}


the supposition that it is indeed these compounds that normally suppress their activity in typical type I tyrosinemia.

In view of the complete resolution of liver disease in this patient under dietary restrictions, and absence of the metabolites considered toxic in this disease, no nitisinone treatment was started. The evolution over the first 6 years of life was entirely uneventful. Nitisinone was started from 6 years to date (current age 12 years), because of a cancer scare (identification and resection of a suspicious liver lesion that proved not malignant). In addition, the lack of hard data on the absence of evolution to end-stage liver disease with hepatocellular carcinoma, or to tubulopathy in this hitherto undescribed type I tyrosinemia inspired prudency in the treating physicians.

Finally, since there apparently can be tyrosinemia presentations without SA in urine and without increased aminolevulinic acid, this has to be taken into account in the interpretation of those newborn screening programs, testing for SA [7] or aminolevulinic acid [8] in urine. The patient presented here would not have been detected by such screening program and nevertheless has proven type I tyrosinemia.

In conclusion, we present a patient homozygous for a previously undescribed mutation in the FAH gene (Ala35Thr), leading to a mild type I tyrosinemia and probably amenable with diet. This mild tyrosinemia presented without urinary SA and SAA.

\section{List of abbreviations}

FAA: fumarylacetoacetate; FAH: fumarylacetoacetate hydrolase or fumarylacetoacetase; SA: succinylacetone; SAA: succinylacetoacetate.

\section{Consent}

Written informed consent was obtained from the patient's parents for publication of this case report and accompanying images. A copy of the written consent is available for review by the Editor-in-Chief of this journal.

\section{Competing interests}

The authors declare that they have no competing interests.

\section{Authors' contributions}

DC, RZ and JJ were involved in the clinical follow-up of the patient, the data analysis and interpretation and drafted the manuscript. EH and EAK performed the biochemical studies, the genetic studies and the interpretation of the results. All authors read and approved the final manuscript.

\section{Acknowledgements}

† Dr. Kvittingen unfortunately passed away before publication of these data, much too soon.

$D C$ is a Fundamenteel-klinisch onderzoeker funded by the FWO-Vlaanderen.

\section{References}

I. Scott CR: The genetic tyrosinemias. Am J Med Genet C Semin Med Genet 2006, 142:121-6.

2. Lindblad B, Steen G: Identification of 4,6-dioxoheptanoic acid (succinylacetone), 3,5-dioxooctanedioic acid (succinylacetoacetate) and 4-0xo-6-hydroxyheptanoic acid in the urine from patients with hereditary tyrosinemia. Biomed Mass Spectrom 1982, 9:419-24.

3. Rootwelt H, Chou J, Gahl WA, Berger R, Coşkun T, Brodtkorb E, Kvittingen EA: Two missense mutations causing tyrosinemia type I with presence and absence of immunoreactive fumarylacetoacetase. Hum Genet 1994, 93(6):615-9.

4. Berger R, Van Faassen H, Taanman JW, De Vries H, Agsteribbe E: Type I tyrosinemia: lack of immunologically detectable fumarylacetoacetase enzyme protein in tissues and cell extracts. Pediatr Res 1987, 22(4):394-8.

5. Kvittingen EA, Rootwelt $H$, Brandtzaeg $P$, Bergan A, Berger $R$ : Hereditary tyrosinemia type I. Self-induced correction of the fumarylacetoacetase defect. J Clin Invest 1993, $91: 1816-21$.

6. Kelsey G, Ruppert S, Beermann F, Grund C, Tanguay RM, Schutz G: Rescue of mice homozygous for lethal albino deletions: implications for an animal model for the human liver disease tyrosinemia type I. Genes Dev 1993, 7:2285-97.

7. Weigel JF, Janzen N, Pfaffle RW, Thiery J, Kiess W, Ceglarek U: Tandem mass spectrometric determination of succinylacetone in dried blood spots enables presymptomatic detection in a case of hepatorenal tyrosinaemia. J Inherit Metab Dis 2007, 30:610.

8. Schulze A, Frommhold D, Hoffmann GF, Mayatepek E: Spectrophotometric microassay for delta-aminolevulinate dehydratase in dried-blood spots as confirmation for hereditary tyrosinemia type I. Clin Chem 200I, 47:1424-9.
Publish with BioMed Central and every scientist can read your work free of charge

"BioMed Central will be the most significant development for disseminating the results of biomedical research in our lifetime. " Sir Paul Nurse, Cancer Research UK

Your research papers will be:

- available free of charge to the entire biomedical community

- peer reviewed and published immediately upon acceptance

- cited in PubMed and archived on PubMed Central

- yours - you keep the copyright

Submit your manuscript here:

http://www.biomedcentral.com/info/publishing_adv.asp
BioMedcentral 